\title{
Concurrent genetic and standard screening test for hearing reduction
}

\author{
Marina Davcheva Chakar ${ }^{1}$, Gjorgji Bozhinovski ${ }^{2}$, \\ Emilija Shukarova Stefanovska ${ }^{2}$, Dejan Trajkov ${ }^{3 *}$ \\ ${ }^{1}$ University Clinic of Otorhinolaryngology, Faculty of Medicine, \\ Ss. Cyril and Methodius University, Vodnjanska 17, 1000 Skopje, \\ Republic of North Macedonia \\ ${ }^{2}$ Research Centre for Genetic Engineering and Biotechnology "Georgi D. Efremov", \\ Macedonian Academy of Science and Art, Boulevard Krste Petkov Misirkov, \\ 1000 Skopje, Republic of North Macedonia \\ ${ }^{3}$ Institute of Immunobiology and Human Genetics, Faculty of Medicine, \\ Ss. Cyril and Methodius University, 50. Divizija 6a, 1000 Skopje, \\ Republic of North Macedonia
}

Received: November 2020; Accepted: December 2020

\begin{abstract}
Reduction of hearing is the most common sensory impairment among newborns with an incidence of 1-3 per 1000 births. Introduction of an Auditory Newborn screening program allows early identification of hearing impairment. Mainly, congenital hearing loss in early childhood is a result of genetic changes. Due to high frequency of GJB2 pathogenic variants, its molecular characterization among sensorineural hearing reduction cases is already conducted as a routine analysis in many countries. The aim of this study is to show our initial results in the effort to determine whether genetic screening along with the standard hearing screening in newborns is justified. Otoacoustic emission (OAE) method was conducted in 223 newborns at risk of hearing impairment. Among them, 7 did not pass the test in both ears while 9 exhibited one-sided hearing loss. In all 7 children with indication of profound bilateral deafness, the diagnosis was confirmed using auditory brainstem response. Genetic screening of GJB2 gene was performed in 6 of them. Genetic analysis of GJB2 revealed homozygous state of the most common pathogenic variant 35delG in 3 (50\%) of the analyzed infants. In the remaining 3 no pathogenic variant was determined. The results indicate that performing auditory OAE together with genetic screening is justified. In newborns who have not passed the hearing screening test and have profound hearing loss, without other syndrome traits, screening for mutations of GJB2 gene should be conducted. Genetic screening enables establishment of early definite diagnosis for deafness and helps in conducting adequate therapy providing timely rehabilitation and social inclusion of deaf child.
\end{abstract}

Keywords: hearing loss, genetic screening, auditory screening, GJB2 gene

\section{Introduction}

Deafness or profound hearing loss is one of the most common congenital abnormalities and presents a huge public health problem. In 1999, following the introduction of hearing screening in newborns, the American Academy of Pediatrics reported that bilateral hearing loss was found in 1-3 per 1000 newborns and in 2-4 per 1000 newborns in the intensive care units (Erenberg et al., 1999). Data from the newborn screening programs in Island, Colorado and Texas have shown that

\footnotetext{
*dejantmk@yahoo.com
} 
2-4 per 1000 newborns have hearing loss (Downs, 1995; Finitzo et al., 1998; Vohr et al., 1998). In another retrospective study, hearing loss was found in 1 per 811 newborns without risk factors and in 1 of 75 newborns with risk factors for hearing loss (Connolly et al., 2005). Successive introduction of the program for universal auditory screening in many countries continually changes the data on prevalence of hearing loss in newborns.

Hearing impairment is a highly heterogeneous condition caused by either environmental or genetic factors. In developed countries hearing impairment due to environmental factors is reduced, mainly due to improved medical care during pregnancy and early childhood. In as many as $50 \%$ of congenitally deaf children, deafness is of genetic nature.

In the etiology of hearing impairment there is also a high genetic heterogeneity. In the last two decades over 110 chromosome loci and more than 65 genes responsible for hearing loss have been identified (http://hereditaryhearingloss.org, accessed November 6, 2020).

About $70 \%$ of cases of genetic deafness are nonsyndromic; deafness is the unique clinical manifestation. Non-syndromic hearing loss is further categorized according to the pattern of inheritance. Of all nonsyndromic hearing impairments, autosomal recessive inheritance has been found in $70-80 \%$, in the remaining $15-20 \%$ autosomal dominant inheritance has been described, in $5 \%$ it has been linked with X-chromosome, and in $1 \%$ due to mitochondrial gene changes (Petersen and Willems, 2006). Beside the extreme genetic heterogeneity, pathogenic variants in one gene, Gap junction beta-2 protein (GJB2), located at DFNB1 locus $(13 q 12.11)$ are the major cause of autosomal nonsyndromic hearing loss (Apps et al., 2007). GJB2 gene encodes synthesis of connexin 26 , protein belonging to the family of membrane proteins that is involved in forming ion channels- connexons, allowing intercellular transport of ions and small molecules.

GJB2 is a small gene with a length of about 5.5 kilobases, with two exons, of which only one contains the coding sequence. The most common defect in this gene is a deletion of guanine $(G)$ in a sequence of six Gs extending from position 30-35 of Cd26 cDNA - (35delG) leading to premature termination of the connexin 26 protein synthesis due to formation of stop codon (Denoyelle et al., 1997). The frequency of this mutation differs among different populations, and shows a large variability in its clinical impact on the hearing impairment. The $35 \mathrm{delG}$ mutation is frequently detected in Caucasian populations (Europe and North America). It is more common in the Mediterranean countries (2.5-4\%), whereas its incidence in the North European countries declines to $1.3 \%$ (Zelante et al., 1997). In addition, more than a hundred different pathogenic variants have also been discovered within this gene, some of them found only once, while some of them appear very frequently among patients with non-syndromic deafness in different ethnic groups (Kennenson et al., 2002).

As a result of the high frequency of GJB2 mutations, determination of spot mutations in this gene in nonsyndromic deafness is conducted as a routine analysis in many countries. The rate of carriers of recessive deafness in the general population, which is associated with GJB2 mutations, is approximately 1 in 33 (Chan and Chang, 2014).

The pattern of inheritance is an autosomal recessive and when present in homozygote state it almost always causes a prelingual, profound deafness (Phillips et al., 2013). In terms of phenotypic traits GJB2 hearing deafness is bilateral, symmetrical and profound to complete deafness (Cryns et al., 2004; Denoyelle et al., 1999). The vestibular function is usually not affected (Denoyelle et al., 1999).

The aim of this study was to determine whether use of genetic screening along with standard hearing screening in newborns is justified.

\section{Case reports}

In the period between 2016 and 2017 hearing screening with the method of otoacoustic emission (OAE) was conducted in 223 newborns at the Audiology Department of the University Clinic for Ear, Nose and Throat, Vodnjanska 17, 1000 Skopje, Republic of North Macedonia. A total of $213(95.5 \%)$ children from this group were with risk factors for hearing impairment (ototoxic medications, premature birth, low birth weight and intensive care longer than 7 days) and the remaining $10(4.5 \%)$ children without risk factors for hearing loss were referred for audiology evaluation due to poor reaction to sound stimuli or poorly developed speaking skills without risk factors for hearing reduction. Of the total of 223 children, 207 (93\%) passed the screening test, $7(3 \%)$ newborns failed the test in both ears, and $9(4 \%)$ newborns passed the test in one ear. In all 7 children who did not pass the OAE, hearing testing with the Auditory Brainstem Response (ABR) method was done and a profound sensorineural hearing impairment was found in both ears. Genetic screening for pathogenic variants in GJB2 gene was conducted in six cases at the Research Centre for Genetic Engineering and Biotechnology "Georgi D. Efremov", Macedonian Academy of Sciences and Arts. Direct sequencing of the coding exon 2 of the GJB2 gene was performed using BigDye Terminator v1.1 kit on ABI Prism 3130 Genetic analyzer (Thermo Fisher Sci., USA). The parents of one of these newborns refused to make the test. A written parental informed consent for genetic testing was obtained. In this paper we will present only three cases with $35 \mathrm{delG}$ pathogenic variant of the GJB2 gene on both chromosomes. The evaluation of every case included family history, physical examination consisting of otologic examination, airway examination, 
standard screening test for hearing, ABR, neurological examination, magnetic resonance imaging (MRI) of temporal bone and genetic test for GJB2 pathogenic variants.

\section{Case 1. Patient A.J.}

A two-month old infant was brought to the Audiology Department due to poor response to sound stimuli. The parents' anamnesis revealed no reaction to the mother's voice, while sharp sound scared the baby. Familial history showed no deaf or hard of hearing members in the family. The baby was of Caucasian origin. Syndromic features were absent. The infant failed the OAE screening in both ears. ABR examination using click stimuli for frequency range of $0.5,1,2$ and $4 \mathrm{kHz}$ showed auditory responses at $80 \mathrm{db}$ intensity only. Neurologic examination and CNS ultrasound evaluation were within normal range. A MRI of temporal bone was conducted as a part of etiologic diagnosis of hearing loss revealing normal temporal bone anatomy of both ears. Genetic analysis revealed presence of the 35delG pathogenic variant of the GJB2 gene on both chromosomes. Soon after the established diagnosis the child was fit with amplifications. The patient underwent a cochlear implantation at the age of 9 months.

\section{Case 2. Patient D.P.}

A three-month old baby was brought to our department due to poor response to sound stimuli. The parents' anamnesis revealed that the baby reacted to sound stimuli until the age of 5.5 months, but it stopped reacting after receiving regular vaccine. Family history revealed no other members with hearing loss. Syndromic features were absent. We performed screening OAE test and ABR. The baby failed the hearing screening. ABR examination using click stimuli for frequency range of $0.5,1,2$ and $4 \mathrm{kHz}$ showed profound deafness; auditory responses were absent at $90 \mathrm{db}$ intensity in both ears. MRI revealed normal temporal bone in both ears. Neurological and ENG results were in normal limits. The $35 \mathrm{delG}$ pathogenic variant of the GJB2 gene was determined in a homozygous state. After three-month hearing aid trial, the infant received cochlear implant.

\section{Case 3. Patient M.S.}

A three-year old child was brought to the Audiology Department due to poorly developed speaking skills. Family history revealed no other members with hearing loss. Syndromic features were absent. The child failed the hearing screening. ABR examination using click stimuli for frequency range of $0.5,1,2$ and $4 \mathrm{kHz}$ showed profound deafness; auditory response at $90 \mathrm{db}$ intensity in both ears. The MRI revealed normal temporal bone in both ears. MRI of temporal bone was conducted revealing normal temporal bone anatomy of both ears. Neurological examination was in the normal range. The $35 \mathrm{delG}$ pathogenic variant of the GJB2 gene was determined in a homozygous state. The child received cochlear implant after three months of establishing the diagnosis.

The intervention in all these cases has being provided in an auditory-verbal setting with improved speech and language skills.

\section{Discussion}

$35 \mathrm{delG}$ pathogenic variant of the GJB2 gene is found in a high percentage among NSHL cases of many countries in north, south and central Europe (28-68\%). The ethnicity of patients is an important variable. The 35 del $\mathrm{G}$ mutation accounts for up to $63 \%$ of the mutant alleles in Caucasians (Gasparini et al., 2000). A high prevalence of $35 \mathrm{delG}(67.49 \%)$ and $\mathrm{W} 24 *(23.01 \%)$ mutations in the GJB2 gene has been determined in patients (Caucasians and Gypsies, respectively) with nonsyndromic inherited deafness in the Republic of Macedonia (Sukarova Stefanovska et al., 2012; Sukarova Stefanovska et al., 2017). Determination of the high prevalence of these two pathogenic variants in GJB2 gene among deaf persons in our Country make the clinician more confident while choosing a test for genetic screening in children who have failed the screening hearing loss test, with profound hearing loss and hearing loss of unknown etiology.

In three children $(50 \%)$ included in this study, who did not pass the hearing test and who were diagnosed with profound hearing loss, the genetic analysis of GJB2 gene mutations showed bi-allelic $35 \mathrm{delG}$ mutation. The results obtained in this study imply the need of genetic testing for GJB2 gene mutations in all children with hearing loss of unknown etiology in line with the recommendations given by other authors (Alford et al., 2014; Kenna et al., 2007).

It is noteworthy to mention that no risk factors at birth were present in any of these children. According to literature data $50 \%$ of children with congenital deafness have no risk factors at birth, and hence a universal newborn hearing screening was introduced in the developed countries many years ago (Alford et al., 2014). Our results indicate the need of implementation of universally accepted hearing screening of newborns in the Republic of North Macedonia.

All three presented cases had a profound hearing loss. These findings correspond with the results obtained in other studies indicating a significant association between genotype of GJB2 gene and the degree of hearing loss (Cryns et al., 2004). Since this condition is recessive, the bi-allelic GJB2 variant in these patients has confirmed the etiology of hearing impairment and helped in timely intervention and auditory speech rehabilitation therapy in these children.

The remaining $3(50 \%)$ children, who underwent analysis of the gene for connexin 26 synthesis, showed no mutation in the gene GJB2 at both chromosomes. The 
cause for hearing impairment in these children was not GJB2 pathogenic variant, but we did not exclude the possibility of other unknown or unexamined genetic causes for hearing loss.

The high prevalence of $35 \mathrm{delG}$ among patients of the examined group implies the need of genetic screening of GJB2 gene pathogenic variants among newborns who have not passed the auditory screening and who have deafness of unknown etiology.

One of our examined children who failed the auditory screening had a bilateral hearing loss and the biallelic GJB2 gene mutation, and was three years old. Unfortunately, there are still cases with severe sensorineural hearing loss that are being diagnosed in older age. There are many reasons responsible for this situation, including not sufficient information and education of parents and above all, lack of universally accepted newborn standard hearing screening in the Republic of North Macedonia.

The results of this study have proved that genetic screening along with newborn hearing screening provide better early identification of hearing deficits and rapid therapeutic intervention. Our results correspond with the results from other studies (Sun et al., 2015; Zhang et al., 2013). Cochlear implantation (CI) is the most important and effective treatment in patients with profound sensorineural hearing loss. All three cases presented in this study, with profound hearing loss and bi-allelic 35 delG pathogenic variant, underwent CI. The intervention in these cases was provided in an auditoryverbal setting with improved speech and language skills. The results are similar to our earlier reported data and are in agreement with the literature revealing that patients with genetic causes hearing loss etiology show good CI speech perception outcomes (Davcheva Chakar et al., 2014; Nishio et al., 2017; Paludetti et al., 2012).

\section{Conclusion}

The high frequency of $35 \mathrm{delG}$ mutation among patients in this study warrants screening for this mutation among infants who did not pass the hearing screening. The results of our study prove that it is beneficial to use genetic screening along with neonatal hearing screening in order to improve early identification of hearing loss and to reach an early decision for cochlear implantation. Therefore, basic scientific knowledge about inherited deafness will be transferred from the laboratory to the patient's bed and will render appropriate medical evaluation and treatment of patients with hearing loss.

\section{References}

Alford, R.L., Arnos, K.S., Fox, M., Lin, J.W., Palmer, C.G., Pandya, A., Rehm, H.L., Robin, N.H., Scott, D.A.,
Yoshinaga-Itano, C., 2014. American College of Medical Genetics and Genomics guideline for the clinical evaluation and etiologic diagnosis of hearing loss. Genet. Med. 16, 347-355. Available at: https://doi.org/10.1038/gim.2014.2.

Apps, S.A., Rankin, W.A., Kurmis, A.P., 2007. Connexin 26 mutations in autosomal recessive deafness disorders: a review. Int. J. Audiol. 46(2), 75-81. Available at: https://doi.org/10.1080/14992020600582190.

Chan, D.K., Chang, K.W., 2014. GJB2-associated hearing loss: systematic review of worldwide prevalence, genotype, and auditory phenotype. Laryngoscope 124(2), E34-53. Available at: https://doi.org/10.1002/lary.24332.

Connolly, J.L., Carron, J.D., Roark, S.D., 2005. Universal newborn hearing screening: are we achieving the Joint Committee on Infant Hearing (JCIH) objectives? Laryngoscope 115(2), 232-236. Available at: https://doi.org/10.1097/01.mlg.0000154724.00787.49.

Cryns, K., Orzan, E., Murgia, A., Huygen, P.L.M., Moreno, F., del Castillo, I., Parker Chamberlin, G., Azaiez, H., Prasad, S., Cucci, R.A., Leonardi, E., Snoeckx, R.L., Govaerts, P.J., Van de Heyning, P.H., Van de Heyning, C.M., Smith, R.J.H., Van Camp, G., 2004. A genotype-phenotype correlation for GJB2 (connexin 26) deafness. J. Med. Genet. 41, 147-154. Available at: https://doi.org/10.1136/jmg.2003.013896.

Davcheva Chakar, M., Sukarova-Stefanovska, E., Ivanovska, V., Sukarova-Stefanovska, E., Lazarevska, V., Filipche, I., Zafirovska, B., 2014. Speech perception outcomes after cochlear implantation in children with GJB2 /DFNB 1 associated deafness. Balkan Med. J. 31(1), 60-63. Available at: https://doi.org/10.5152/balkanmedj.2014.9535.

Denoyelle, F., Weil, D., Maw, M.A, Wilcox, S.A., Lench, N.J., Allen-Powell, D.R., Osborn, A.H., Dahl, H-H.M., Middleton, A., Houseman, M.J., Dodé, C., Marlin, S., Boulila-ElGaïed, A., Grati, M., Ayadi, H., BenArab, S., Bitoun, P., Lina-Granade, G., Godet, J., Mustapha, M., Loiselet, J., El-Zir, E., Aubois, A., Joannard, A., Levilliers J., Garabédian, E-N., Mueller, R., McKinlay Gardner, R.J., Petit, C., 1997. Prelingual deafness: High prevalence of a 30delG mutation in the connexin 26 gene. Human Molecular Genetics 6, 2173-2177. Available at: https://doi.org/10.1093/hmg/6.12.2173.

Denoyelle, F., Marin, S., Weil, D., Moatti, L., Chauvin, P., Garabédian, E.N., Petit, C., 1999. Clinical features of the prevalent form of the childhood deafness DFNB1, due to a connexin 26 gene defect implications for genetic counseling. Lancet 353(9161), 1298-1303. Available at: https://doi.org/10.1016/S0140-6736(98)11071-1.

Downs, M.P., 1995. Universal newborn hearing screening--the Colorado story. Int. J. Pediatr. Otorhinolaryngol. 32(3), 257-259. Available at: https://doi.org/10.1016/01655876(95)01183-c.

Erenberg, A., Lemons, J., Sia, C., Trunkel, D., Ziring, P., 1999. Newborn and infant hearing loss: detection and intervention. American Academy of Pediatrics. Task Force on Newborn and Infant Hearing, 1998-1999. Pediatrics 103(2), 527-30. Available at: https://doi.org/10.1542/peds.103.2.527.

Finitzo, T., Albright, K., O'Neal, J., 1998. The newborn with hearing loss: detection in the nursery. Pediatrics 102(6), 1452-1460. Available at: https://doi.org10.1542/peds.102.6.1452. 
Gasparini, P., Rabionet, R., Barbujani, G., Melchionda, S., Petersen, M., Brondum-Nielsen, K., Metspalu, A., Oitmaa, E., Pisano, M., Fortina, P., Zelante, L., Estivill, X., 2000. High carrier frequency of the 35 delG deafness mutation in European populations. Eur. J. Hum. Gen. 8(1), 19-23. Available at: https://doi.org/10.1038/sj.ejhg.5200406. http://hereditaryhearingloss.org )Last accessed: November 6, 2020)

Kenna, M.A., Rehm, H.L., Robson, C.D., Frangulov, A., McCallum, J., Yaeger, D., Krantz, I.D., 2007. Additional clinical manifestations in children with sensorineural hearing loss and biallelic GJB2 mutations: who should be offered GJB2 testing? Am. J. Med. Genet. 143A(14), 15601566. Available at: https://doi.org/10.1002/ajmg.a.31706.

Kennenson, A., Van Naarden Brown, K., Boyle, C., 2002. GJB2 (connexin 26) variants and nonsyndromic sensorineural hearing loss: A HuGE review. Genet. Med. 4(4), 258-274. Available at: https://doi.org/10.1097/00125817-20020700000004.

Nishio, S.Y., Usami, S.I., 2017. Outcomes of the cochlear implantation for the patients with specific genetic etiologies: A systematic literature review. Acta Otolaryngol. 137(7), 730-742. Available at: https://doi.org/10.1080/00016489.2016.1276303.

Paludetti, G., Conti, G., Di Nardo, W., De Corso, E., Rolesi, R., Piccotti, P.M., Fetoni, A.R., 2012. Infant hearing loss: from diagnosis to therapy. Acta otorhinolaryngologica Italica 32(6), 347-370.

Petersen, M.B., Willems, P.J., 2006. Non-syndromic, autosomalrecessive deafness. Clin. Genet. 69(5), 371-392. Available at: https://doi.org/10.1111/j.1399-0004.2006.00613.x.

Phillips, L.L., Bitner-Glindzicz, M., Lench, N., Steel, K.P., Langford, C., Dawson, S.J., Davis, A., Simpson,S., Packer, C., 2013. The future role of genetic screening to detect newborns at risk of childhood- onset hearing loss. Int. J. Audiol. 52(2), 124-133. Available at: https://doi.org/10.3109/14992027.2012.733424.
Sukarova Stefanovska, E., Chakar, M., Filipche, I., Plaseska Karanfilska, D., 2012. Genetics of non-syndromic hearing loss in R. Macedonia. BJMG 15(Suppl.), 37-39. Available at: https://doi.org/10.2478/v10034-012-0020-0.

Sukarova Stefanovska, E., Bozhinovski, G., Momirovska, A., Davceva Cakar, M., Sukarova-Angelovska, E., PlaseskaKaranfilska, D., 2017. Mutation analysis of the common deafness genes in patients with nonsyndromic hearing loss in Republic of Macedonia. Mac. Med. Review 71(1), 2026. Available at: https://doi.org/10.1515/mmr-2017-0005.

Sun, X., Xi, Z., Zhang, J., Liu, B., Xing, X., Huang, X., Zhao, Q., 2015. Combined hearing and deafness gene mutation screening in 11,046 Chinese newborns. Chinese J. Med. Genet. 32(6), 766-770. Available at: https://doi.org/10.3760/cma.j.issn.1003-9406.2015.06.002.

Vohr, B.R., Carty, L.M., Moore, P.E., Letourneau, K., 1998. The Rhode Island Hearing Assessment Program: experience with statewide hearing screening (1993-1996). J. Pediatr. 133(3), 353-357. Available at: https://doi.org/10.1016/s0022-3476(98)70268-9.

Zelante, L., Gasparini, P., Estivill, X., Melchionda, S., D'Agruma, L., Govea, N., Milá, M., Monica, M.D., Lutfi, J., Shohat, M., Mansfield, E., Delgrosso, K., Rappaport, E., Surrey, S., Fortina, P., 1997. Connexin 26 mutations associated with the most common form of non-syndromic neurosensory autosomal recessive deafness (DFNB1) in Mediterraneans. Hum. Mol. Genet. 6(9), 1605-1609. Available at: https://doi.org/10.1093/hmg/6.9.1605.

Zhang, J., Wang, P., Han, B., Ding, Y., Pan, L., Zou, J., Liu, H., Pang, X., Liu, E., Wang, H., Liu, H., Zhang, X., Cheng, X., Feng, D., Li, Q., Wang, D., Zong, L., Yi, Y., Tian, N., Mu, F., Tian, G., Chen, Y., Liu, G., Zhang, F., Yi, X., Yang, L., Wang, Q., 2013. Newborn hearing concurrent genetic screening for hearing impairment-a clinical practice in 58,397 neonates in Tianjin, China. Int. J. Pediatr. Otorhinolaryngol. 77(12), 1929-1935. Available at: https://doi.org/10.1016/j.ijporl.2013.08.038. 


\title{
Резиме
}

\section{Истовремено спроведување на генетски и стандарден тест при скрининг кај новородени со редукција на слухот}

\author{
Марина Давчева Чакар ${ }^{1}$, Ѓрѓ́ Божиновски ${ }^{2}$ Емилија Шукаровска Стефанова ${ }^{2}$, \\ Дејан Трајков ${ }^{3 *}$ \\ ${ }^{1}$ Универзитетска клиника за оториноларингологија, Медицински факултет, \\ Универзитет „Св. Кирил и Методиј”, Водюанска 17, 1000 Скопје, \\ Република Северна Македонија \\ ${ }^{2}$ Истражувачки иентар за генетско инжињерство и биотехнологија \\ „Горѓи Д. Ефремов”, Македонска академија на науки и уметности, \\ Булевар Крсте Петков Мисирков, 1000 Скопје, Република Северна Македонија \\ ${ }^{3}$ Институт за имунобиологија и хумана генетика, Медицински факултет, \\ Универзитет „,Св. Кирил и Методиј”, 50 Дивизија 6а, 1000 Скопје, \\ Република Северна Македонија
}

Клучни зборови: редукција на слух, генетски скрининг, аудиторен скрининг, GJB2 ген

Намалување на слухот е најчестото сензорно оштетување кај новороденчињата со инциденца од 1-3 на 1000 раѓања. Воведување на програма за аудитивен скрининг на новороденчиња овозможува рано идентификување на оштетувањето на слухот. Главно, вроденото губење на слухот во раното детство е резултат на генетски промени. Поради големата фреквенција на патогени варијанти на GJB2 меѓу новородените со сензоринеурална редукција на слухот, во многу земји неговата молекуларна карактеризација веќе се спроведува како рутинска анализа. Целта на овој труд е да ги прикажеме нашите почетни резултати во напорот да утврдиме дали е оправдана употребата на генетскиот скрининг заедно со стандардниот скрининг за слух кај новороденчињата. Методата на отокустична емисија (ОАЕ) беше спроведена кај 223 новороденчиња со ризик од оштетување на слухот. Меѓу нив, 7 не го поминаа тестот на двете уши, додека 9 покажаа постоење на еднострано губење на слухот. Кај сите 7 деца со индикација за постоење на тешка билатерална глувост, дијагнозата е потврдена со методата на аудитиви одговори на мозочното стебло. Генетскиот скрининг на генот GJB2 е извршен кај 6 од нив. Генетската анализа на GJB2 откри присуство на хомозиготна форма на најчестата патогена варијанта 35delG кај 3 (50\%) од анализираните доенчиња. Во преостанатите 3 не е утврдено постоење на оваа форма. Резултатите укажуваат дека е оправдано спроведување на аудитивни ОАЕ заедно со генетскиот скрининг. Кај новороденчињата кои не го поминале скрининг тестот и имаат тешка редукција на слухот, без други карактеристики на синдромска наглувост, треба да се спроведе скрининг за мутации на генот GJB2. Генетскиот скрининг овозможува воспоставување на рана дефинитивна дијагноза за глувост и помага при спроведување на соодветна терапија која обезбедува навремена рехабилитација и социјална рехабилитација на глувите. 